\title{
ESTIMATION OF THE OPTIMUM SIZE OF PLOTS FOR SOYBEAN RADIOMETER EXPERIMENTS
}

\author{
Roger Nabeyama MICHELS ${ }^{1}$ \\ Marcelo Giovanetti CANTERI ${ }^{2}$ \\ Marcelo Augusto de AGUIAR E SILVA ${ }^{2}$ \\ Janksyn BERTOZZI ${ }^{1}$ \\ Tatiane Cristina DAL BOSCO ${ }^{1}$
}

- ABSTRACT: The lack of error of experimental planning in agricultural field studies can result in rework, causing the waste of financial resources. The determination of the optimal size of the experimental plot for carrying out the treatments can minimize these problems. The objective of this paper was to estimate the optimal plot size for measuring reflectance in soybeans, without treatment, using the modified maximum curvature method and the maximum distance method. Reflectance readings were taken in the soybean crop with the aid of the GreenSeeker ${ }^{\circledR}$ equipment, in basic experimental units of $0.45 \mathrm{~m}^{2}$, in an area of 7 lines and 8 meters in length. The data were collected in three phenological stages of soy (R4, R5.5 and R6), obtaining 63 simulations of experimental area in each stage. Based on the results, it is recommended to use plots of $7.20 \mathrm{~m}^{2}$, with grouping of 4 lines of $4 \mathrm{~m}$ in length.

- KEY WORDS: Maximum modified curvature; Maximum distance; NDVI.

\section{Introduction}

The use of optical proximity sensors is a promising technique for crop management, as it is an accurate and non-destructive method (CARNEIRO et al., 2019, STOCHER et al., 2019), and can be used to detect variations in the leaf area of plants attacked by diseases or deficiency in fertilization, serving as a parameter to estimate damage in production (CEREZINI et al., 2016; KAPP JUNIOR, 2016; BENEDUZZI et al., 2017; SANTOS et al., 2017).

The GreenSeeker ${ }^{\circledR}$, an active spectral sensor, is an instrument that provides the normalized difference vegetation index (NDVI) via reflectance measurements, this sensor automatically generates NDVI readings from the spectral response of the red bands (650 $\mathrm{nm})$ and nera-infrared (770 nm) (COELHO et al., 2019).

For experiments that use reflectance as a parameter to determine the damage and severity of leaf diseases, deficiency in fertilization and crop productivity, it is necessary to check the ideal plot size in order to minimize errors (MICHELS et al., 2015).

\footnotetext{
${ }^{1}$ Universidade Tecnológica Federal do Paraná - UTFPR, Campus Londrina, Departamento Acadêmico de Engenharia Mecânica, Londrina, PR, Brasil. E-mail: rogernmichels@utfpr.edu.br; janksynbertozzi@utfpr.edu.br; tatianebosco@utfp.edu.br

${ }^{2}$ Universidade Estadual de Londrina - UEL, Centro de Ciências Agrárias, Londrina, PR, Brasil. E-mail: canteri@uel.br; aguiaresilva@uel.br 
Experimental planning for the proper choice of plot size is an indispensable procedure for performing tests with experimental precision of acceptable magnitude (SCHWERTNER et al., 2015). When the experimental area is not a limiting factor, it is better to increase the number of repetitions than the plot size (LÚCIO and SARI, 2017). Saving human and financial resources, without losing experimental precision, is considered an important factor in the design of experiments (MICHELS et al., 2015; LÚCIO and SARI, 2017).

The establishment of an optimal plot size directly interferes with the implementation of any experiment and is one of the ways to increase the experimental precision and maximize the information obtained during an experiment (LÚCIO and SARI, 2017), in addition to being a recognized way to reduce experimental error, there are several methods for its estimation, based on different principles (LORENTZ et al., 2012).

To determine the optimum plot size using the modified maximum curvature (MMC) method and the distance maximum (MD) method it is required one experiment with the culture of interest without any treatment. Then, it is necessary to do the subdivision of the experimental area into smaller portions, called basic experimental units (BEU), from which data are collected the data independently, identifying the relative position. After taking the data, plots of different sizes and shapes are simulated, by adding the contiguous plots (LORENTZ et al., 2012).

The aim of this paper was to estimate the optimal plot size for evaluating reflectance in soybean experiments using the modified maximum curvature and the maximum distance methods.

\section{Material and methods}

The experiment was conducted at the State University of Londrina (UEL), located in the municipality of Londrina, PR, Brazil, at $23^{\circ} 19^{\prime} 40,92^{\prime \prime}$ south latitude and $51^{\circ} 12^{\prime} 19,20^{\prime \prime}$ west longitude and $560 \mathrm{~m}$ altitude, in the 2013/14 harvest. Sowing was carried out on 12/05/2013. The soybean cultivar used was Monsoy 6410 IPRO, which features RR (Roundup Ready) technology and is caterpillar resistant. Another factor, which could affect the leaf cover, and consequently the reflectance values, are fungal diseases and to circumvent this problem, 6 fungicide applications were carried out in a scheduled manner. The commercial mixture used was Piraclostrobin + Epoxiconazole, applied at a dose of 500 mL.ha ${ }^{-1}$ per 200 L.ha $^{-1}$ mix volume and supplemented with mineral oil as the vehicle, at the same dose as the fungicide.

The conduction of the experiment was carried out in an area of $10 \mathrm{~m}$ by 9 lines, with a spacing between lines of $0.45 \mathrm{~m}$ and the useful area was defined as a central area of 32.4 $\mathrm{m}^{2}$, that is, 7 lines of $8 \mathrm{~m}$.

The reflectance readings, performed with the aid of the NTech GreenSeeker $®$, model RT100, were taken by a single operator, following the same path in the planting in all readings, in the reproductive stages $\mathrm{R} 4, \mathrm{R} 5.5$ and R6, with the sensor at a height of $0.80 \mathrm{~m}$ from the canopy of the crop, between 8 am and 8:30 am, on the 7 central lines, at 1 meter intervals, totaling $8 \mathrm{~m}$ per line and 56 readings per stadium. The basic experimental units (BEU) were set at $0.45 \mathrm{~m}^{2}$, obtained through the smallest form obtained: $0.45 \mathrm{~m} \mathrm{x} 1.00 \mathrm{~m}$.

The stages R4, R5.5 and R6 were chosen because they have maximum leaf coverage (R4), starting with a decrease in leaf area (R5.5) and the beginning of senescence of plants 
(R6). In figure 1, it is possible to verify the dispersion of the readings and the reduction of leaf coverage according to each stage.

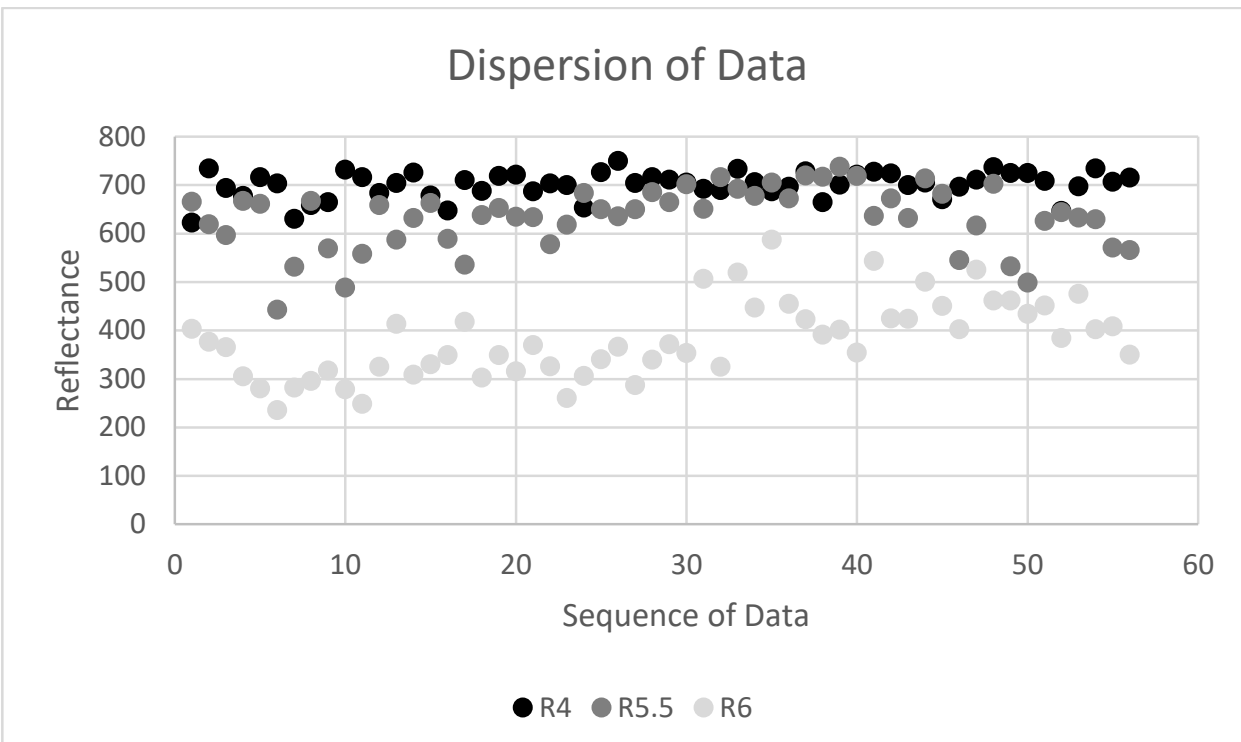

Figure 1 - Dispersion of reflectance data at stages R4, R5.5 and R6.

The optimal plot size was estimated using, initially, the modified maximum curvature (MMC) method, proposed by Lessman and Atkins (1963) apud Meier and Lessman (1971). In this method, the measure of variability given by the coefficient of variation $\left(\mathrm{CV}_{\mathrm{x}}\right)$ and the size of the plot with $\mathrm{X}$ basic experimental units is clarified by $C V_{x}-a X^{-b}$, where a and $\mathrm{b}$ are the parameters to be estimated. The optimal plot size was estimated by the expression:

$$
X_{0}=\exp \left\{\left[\frac{1}{2 b+2}\right] \log \left[\frac{(a b)^{2}(2 b+1)}{b+2}\right]\right\}
$$

where, $X_{0}$ is the value of the abscissa at the point of maximum curvature, which corresponds to the optimal size of the plot (MEIER and LESSMAN, 1971). To confirm the results, in addition to the coefficient of variation $\left(C V_{x}\right)$, all calculations were repeated with the data of variance $\left(V_{x}\right)$, clarified by $V_{x}=a X^{-b}$.

According to Paranaíba et al. (2009) it is recommended to use more than one method for determining the optimal size of experimental plots. Thus, the maximum distance (MD) method was used later, where its resolution starts from the geometry formed by a $y_{c}$ curve, described by $y_{c}=a X^{-b}$, and a secant line to this curve, $\mathrm{y}_{\mathrm{r}}$. We sought the point on the $y_{c}$ curve that was the longest distance from the $y_{r}$ line, as long as the line segment along that distance was perpendicular to the $y_{r}$ line (LORENTZ et al., 2012).

The solution method presented by Lorentz et al. (2012) proposes to express the straight line perpendicular to the $y_{r}$ line, as an aid to find the desired point of the $y_{c}$ curve. Thus, this 
straight line perpendicular to the $y_{r}$ line is called $y_{p}$, expressed by $y_{p}=e x+f$. The slope $\mathrm{c}$ and the linear coefficient d, both of the yr line, are fixed and can be obtained from two points of $y_{r}$ common to the $y_{c}$ curve.

The point in common between $y_{c}$ and $y_{r}$ that is on the left, given by $\left(x_{c r i}, y_{c r i}\right)$, and the point in common, the most direct, is given by $\left(x_{c r f}, y_{c r f}\right)$. Then $c$ and $d$ are expressed, respectively, by: $c=y_{c r f}-y_{c r i} / x_{c r f}-x_{c r i}$ and $d=y_{c r i}-c x_{c r i}$ or $d=y_{c r f}-c x_{c r f}$ these expressions for $\mathrm{d}$ being obtained, isolating themselves in the equation for $y_{r}$, having been replaced in this, the point $\left(x_{c r i}, y_{c r i}\right)$, or the point $\left(x_{c r f}, y_{c r f}\right)$. The slope and line $y_{p}$ is also fixed and can be obtained, using the condition that the lines $y_{r}$ and $y_{p}$ are perpendicular to each other. In this way $e=-1 / c$ (LORENTZ et al., 2012).

The determination of the linear coefficient $\mathrm{f}$ of the line $y_{p}$ is part of the iterative method proposed by Lorentz et al. (2012) and whose solution is: $x_{r p j}=f-d / c-e$.

The distance between the points $\left(x_{c j}, x_{c j}\right)$ and $\left(x_{r p j}, x_{r p j}\right)$, distance is on the line $y_{p j}$, which is perpendicular to $y_{r}$, is dated by:

$$
d_{c r}=\sqrt{\left(y c_{j}-y_{r p j}\right)^{2}+\left(x c_{j}-x_{r p j}\right)^{2}}
$$

The analyzes were performed within each phenological stage (R4, R5.5, and R6). Thus, each phenological stage can be considered as a blank treatment, according to research developed by Lorentz et al. (2012).

To determine the optimal plot size, the UEB grouping of the NDVI data collected is necessary to determine the area and the number of the plots. Table 1 shows the simulations, the width in meters, the length of $0.45 \mathrm{~m}$ of each unit, the relationship between length and width (LxW), plot size in $\mathrm{m}^{2}$, the type of grouping and the number of plots. The BEU in this paper is considered $0.45 \mathrm{~m}^{2}$, that is, $1 \mathrm{~m}$ long by $0.45 \mathrm{~m}$ wide.

Calculations were performed to determine the optimal plot size using simulations 1 to 63,1 to 43 and 1 to 23 , in order to obtain a more significant $R^{2}$. 
Table 1 - Units of width and length, combination of length and width $(\mathrm{LxW})$, plot size $\left(\mathrm{m}^{2}\right)$, type of grouping $(\mathrm{m})$ and total number of plots

\begin{tabular}{|c|c|c|c|c|c|c|}
\hline Simulation & Length & Width & $\mathrm{LxW}$ & Size $\left(m^{2}\right)$ & $\begin{array}{c}\text { Type of grouping } \\
(\mathrm{m})\end{array}$ & $\begin{array}{c}\text { Number of } \\
\text { plots }\end{array}$ \\
\hline 1 & 1 & 1 & 1 & $0.45 \mathrm{~m}^{2}$ & $0.45 \times 1.00$ & 162 \\
\hline 2 & 1 & 2 & 2 & $0.90 \mathrm{~m}^{2}$ & $0.45 \times 2.00$ & 72 \\
\hline 3 & 2 & 1 & 2 & $0.90 \mathrm{~m}^{2}$ & $0.90 \times 1.00$ & 81 \\
\hline 4 & 3 & 1 & 3 & $1.35 \mathrm{~m}^{2}$ & $1.35 \times 1.00$ & 54 \\
\hline 5 & 1 & 3 & 3 & $1.35 \mathrm{~m}^{2}$ & $0.45 \times 3.00$ & 54 \\
\hline 6 & 4 & 1 & 4 & $1.80 \mathrm{~m}^{2}$ & $1.80 \times 3.00$ & 36 \\
\hline 7 & 2 & 2 & 4 & $1.80 \mathrm{~m}^{2}$ & $0.90 \times 2.00$ & 36 \\
\hline 8 & 1 & 4 & 4 & $1.80 \mathrm{~m}^{2}$ & $0.45 \times 4.00$ & 36 \\
\hline 9 & 5 & 1 & 5 & $2.25 \mathrm{~m}^{2}$ & $2.25 \times 1.00$ & 27 \\
\hline 10 & 1 & 5 & 5 & $2.25 \mathrm{~m}^{2}$ & $0.45 \times 5.00$ & 18 \\
\hline 11 & 6 & 1 & 6 & $2.70 \mathrm{~m}^{2}$ & $2.70 \times 1.00$ & 27 \\
\hline 12 & 3 & 2 & 6 & $2.70 \mathrm{~m}^{2}$ & $1.35 \times 2.00$ & 24 \\
\hline 13 & 1 & 6 & 6 & $2.70 \mathrm{~m}^{2}$ & $0.45 \times 6.00$ & 18 \\
\hline 14 & 2 & 3 & 6 & $2.70 \mathrm{~m}^{2}$ & $0.90 \times 3.00$ & 27 \\
\hline 15 & 1 & 7 & 7 & $3.15 \mathrm{~m}^{2}$ & $0.45 \times 7.00$ & 18 \\
\hline 16 & 7 & 1 & 7 & $3.15 \mathrm{~m}^{2}$ & $3.15 \times 1.00$ & 18 \\
\hline 17 & 1 & 8 & 8 & $3.60 \mathrm{~m}^{2}$ & $0.45 \times 8.00$ & 18 \\
\hline 18 & 8 & 1 & 8 & $3.60 \mathrm{~m}^{2}$ & $3.60 \times 1.00$ & 18 \\
\hline 19 & 4 & 2 & 8 & $3.60 \mathrm{~m}^{2}$ & $1.80 \times 2.00$ & 16 \\
\hline 20 & 2 & 4 & 8 & $3.60 \mathrm{~m}^{2}$ & $0.90 \times 4.00$ & 18 \\
\hline 21 & 3 & 3 & 9 & $4.05 \mathrm{~m}^{2}$ & $1.35 \times 3.00$ & 18 \\
\hline 22 & 5 & 2 & 10 & $4.50 \mathrm{~m}^{2}$ & $2.25 \times 2.00$ & 12 \\
\hline 23 & 2 & 5 & 10 & $4.50 \mathrm{~m}^{2}$ & $0.90 \times 5.00$ & 9 \\
\hline 24 & 4 & 3 & 12 & $5.40 \mathrm{~m}^{2}$ & $1.80 \times 3.00$ & 12 \\
\hline 25 & 6 & 2 & 12 & $5.40 \mathrm{~m}^{2}$ & $2.70 \times 2.00$ & 12 \\
\hline 26 & 3 & 4 & 12 & $5.40 \mathrm{~m}^{2}$ & $1.35 \times 4.00$ & 12 \\
\hline 27 & 2 & 6 & 12 & $5.40 \mathrm{~m}^{2}$ & $0.90 \times 6.00$ & 9 \\
\hline 28 & 5 & 3 & 15 & $6.75 \mathrm{~m}^{2}$ & $2.25 \times 3.00$ & 9 \\
\hline 29 & 3 & 5 & 15 & $6.75 \mathrm{~m}^{2}$ & $1.35 \times 5.00$ & 6 \\
\hline 30 & 2 & 7 & 14 & $6.30 \mathrm{~m}^{2}$ & $0.90 \times 7.00$ & 9 \\
\hline 31 & 7 & 2 & 14 & $6.30 \mathrm{~m}^{2}$ & $3.15 \times 2.00$ & 8 \\
\hline 32 & 4 & 4 & 16 & $7.20 \mathrm{~m}^{2}$ & $1.80 \times 4.00$ & 8 \\
\hline 33 & 2 & 8 & 16 & $7.20 \mathrm{~m}^{2}$ & $0.90 \times 8.00$ & 9 \\
\hline 34 & 8 & 2 & 16 & $7.20 \mathrm{~m}^{2}$ & $3.60 \times 2.00$ & 8 \\
\hline 35 & 6 & 3 & 18 & $8.10 \mathrm{~m}^{2}$ & $2.70 \times 3.00$ & 9 \\
\hline 36 & 3 & 6 & 18 & $8.10 \mathrm{~m}^{2}$ & $1.35 \times 6.00$ & 6 \\
\hline 37 & 5 & 4 & 20 & $9.00 \mathrm{~m}^{2}$ & $2.25 \times 4.00$ & 6 \\
\hline 38 & 4 & 5 & 20 & $9.00 \mathrm{~m}^{2}$ & $1.80 \times 5.00$ & 4 \\
\hline 39 & 7 & 3 & 21 & $9.45 \mathrm{~m}^{2}$ & $3.15 \times 3.00$ & 6 \\
\hline 40 & 3 & 7 & 21 & $9.45 \mathrm{~m}^{2}$ & $1.35 \times 7.00$ & 6 \\
\hline
\end{tabular}


Table 1 (Continuation) - Units of width and length, combination of length and width (LxW), plot size $\left(\mathrm{m}^{2}\right)$, type of grouping $(\mathrm{m})$ and total number of plots

\begin{tabular}{ccccccc}
\hline Simulation & Length & Width & LxW & Size $\left(\mathrm{m}^{2}\right)$ & $\begin{array}{c}\text { Type of grouping } \\
(\mathrm{m})\end{array}$ & $\begin{array}{c}\text { Number of } \\
\text { plots }\end{array}$ \\
\hline 41 & 8 & 3 & 24 & $10.80 \mathrm{~m}^{2}$ & $3.60 \times 3.00$ & 6 \\
42 & 3 & 8 & 24 & $10.80 \mathrm{~m}^{2}$ & $1.35 \times 8.00$ & 6 \\
43 & 6 & 4 & 24 & $10.80 \mathrm{~m}^{2}$ & $2.70 \times 4.00$ & 6 \\
44 & 4 & 6 & 24 & $10.80 \mathrm{~m}^{2}$ & $1.80 \times 4.00$ & 4 \\
45 & 5 & 5 & 25 & $11.25 \mathrm{~m}^{2}$ & $2.25 \times 5.00$ & 3 \\
46 & 7 & 4 & 28 & $12.60 \mathrm{~m}^{2}$ & $3.15 \times 4.00$ & 4 \\
47 & 4 & 7 & 28 & $12.60 \mathrm{~m}^{2}$ & $1.80 \times 7.00$ & 4 \\
48 & 6 & 5 & 30 & $13.50 \mathrm{~m}^{2}$ & $2.70 \times 5.00$ & 3 \\
49 & 5 & 6 & 30 & $13.50 \mathrm{~m}^{2}$ & $2.25 \times 6.00$ & 3 \\
50 & 8 & 4 & 32 & $14.40 \mathrm{~m}^{2}$ & $3.60 \times 4.00$ & 4 \\
51 & 4 & 8 & 32 & $14.40 \mathrm{~m}^{2}$ & $1.80 \times 8.00$ & 4 \\
52 & 7 & 5 & 35 & $15.75 \mathrm{~m}^{2}$ & $3.15 \times 5.00$ & 2 \\
53 & 5 & 7 & 35 & $15.75 \mathrm{~m}^{2}$ & $2.25 \times 7.00$ & 3 \\
54 & 6 & 6 & 36 & $16.20 \mathrm{~m}^{2}$ & $2.70 \times 6.00$ & 3 \\
55 & 8 & 5 & 40 & $18.00 \mathrm{~m}^{2}$ & $3.60 \times 5.00$ & 2 \\
56 & 5 & 8 & 40 & $18.00 \mathrm{~m}^{2}$ & $2.25 \times 8.00$ & 3 \\
57 & 7 & 6 & 42 & $18.90 \mathrm{~m}^{2}$ & $3.15 \times 6.00$ & 2 \\
58 & 6 & 7 & 42 & $18.90 \mathrm{~m}^{2}$ & $2.70 \times 7.00$ & 3 \\
59 & 7 & 7 & 49 & $22.05 \mathrm{~m}^{2}$ & $3.15 \times 7.00$ & 2 \\
60 & 8 & 6 & 48 & $21.60 \mathrm{~m}^{2}$ & $3.60 \times 8.00$ & 2 \\
61 & 6 & 8 & 48 & $21.60 \mathrm{~m}^{2}$ & $2.70 \times 8.00$ & 3 \\
62 & 7 & 8 & 56 & $25.20 \mathrm{~m}^{2}$ & $3.15 \times 8.00$ & 2 \\
63 & 8 & 7 & 56 & $25.20 \mathrm{~m}^{2}$ & $3.60 \times 7.00$ & 2 \\
\hline
\end{tabular}

\section{Results and discussion}

In order to estimate the optimal plot size using the modified maximum curvature (MMC) method, it is necessary to obtain the values of the estimates a and b presented by Lessman and Atkins (1963) and Meier and Lessman, (1971) and by the method of maximum distance (MD), it is also necessary to the values of $\mathrm{c}, \mathrm{d}$ and e the linear and angular coefficients of the lines yr and yp (LORENTZ et al., 2012), values presented in Table 2, for the data of coefficient of variation $(\mathrm{CV})$ and in Table 3, for the data of variance $(\mathrm{V})$. 
Table 2 - Values of Lessman and Atkins estimates $a$ e $b$, slope $c$ and linear coefficient $d$ of the $\mathrm{y}_{\mathrm{r}}$ line, slope $\mathrm{e}$ of the $\mathrm{y}_{\mathrm{p}}$ line and $\mathrm{R}^{2}$ using the $\mathrm{CV}$

\begin{tabular}{cccccccc}
\hline Stages & Simulation & $\mathrm{a}$ & $\mathrm{b}$ & $\mathrm{c}$ & $\mathrm{d}$ & $\mathrm{e}$ & $\mathrm{R}^{2}$ \\
\hline \multirow{3}{*}{$\mathrm{R} 4$} & 63 & 4.0808 & 0.313 & -0.0539 & 4.1347 & 18.5529 & 0.702 \\
& 43 & 4.4468 & 0.355 & -0.1425 & 4.5893 & 7.0175 & 0.847 \\
& 23 & 4.7533 & 0.398 & -0.3765 & 5.1298 & 2.6560 & 0.808 \\
\hline \multirow{3}{*}{$\mathrm{R} 5.5$} & 63 & 9.8126 & 0.382 & -0.0945 & 9.9071 & 10.582 & 0.466 \\
& 43 & 10.830 & 0.234 & -0.2756 & 11.106 & 3.6284 & 0.671 \\
& 23 & 11.307 & 0.265 & -0.7090 & 12.016 & 1.4104 & 0.731 \\
\hline \multirow{3}{*}{$\mathrm{R} 6$} & 63 & 18.653 & 0.292 & -0.2380 & 18.891 & 4.2016 & 0.381 \\
& 43 & 19.308 & 0.310 & -0.5779 & 19.886 & 1.7304 & 0.373 \\
& 23 & 18.771 & 0.291 & -1.2482 & 20.019 & 0.8015 & 0.405 \\
\hline
\end{tabular}

Table 3 - Values of Lessman and Atkins estimates $a$ e $b$, slope $c$ and linear coefficient $d$ of the $\mathrm{y}_{\mathrm{r}}$ line, slope $\mathrm{e}$ of the $\mathrm{y}_{\mathrm{p}}$ line and $\mathrm{R}^{2}$ using the $\mathrm{V}$

\begin{tabular}{cccccccc}
\hline Stages & Simulation & $\mathrm{a}$ & $\mathrm{b}$ & $\mathrm{c}$ & $\mathrm{d}$ & $\mathrm{e}$ & $\mathrm{R}^{2}$ \\
\hline \multirow{3}{*}{$\mathrm{R} 4$} & 63 & 868.79 & 0.7551 & -14.709 & 883.5 & 0.06799 & 0.755 \\
& 43 & 988.31 & 0.8501 & -39.186 & 1027.5 & 0.02552 & 0.850 \\
& 23 & 1126.9 & 0.8128 & -114.76 & 1241.7 & 0.00871 & 0.813 \\
\hline \multirow{3}{*}{ R5.5 } & 63 & 3645.9 & 0.3750 & -52.271 & 3698.2 & 0.01913 & 0.487 \\
& 43 & 4415.2 & 0.4740 & -159.58 & 4574.9 & 0.00627 & 0.686 \\
& 23 & 4823.7 & 0.5370 & -436.45 & 5260.2 & 0.00229 & 0.748 \\
\hline \multirow{3}{*}{ R6 } & 63 & 4680.4 & 0.3840 & -77.714 & 4758.1 & 0.01287 & 0.384 \\
& 43 & 5020.3 & 0.3742 & -197.55 & 5217.9 & 0.00506 & 0.374 \\
& 23 & 4751.3 & 0.4048 & -444.91 & 5196.2 & 0.00225 & 0.405 \\
\hline
\end{tabular}

For the three stages of the culture in which the NDVI data were collected (R4, R5.5 and R6) and in the three simulations performed, using the MMC method, using the CV and $\mathrm{V}$ data, it was obtained as the optimum size from plot to area of $0.45 \mathrm{~m}^{2}$, length to width ratio equal to 1, that is, area equal to BEU (Table 4). According to Paranaíba et al. (2009), the maximum curvature method may underestimate the plot size, due to the low values of the variation coefficient that, according to Lorentz et al. (2012) influences the estimate of the optimal plot size.

The MD method for $\mathrm{V}$ data, for all possibilities, obtained the optimal plot size equal to $1 \mathrm{BEU}$ (Table 4).

For CV data for 23 simulations in the three stages, the estimate of the optimal plot size was $1.35 \mathrm{~m}^{2}(\mathrm{LxW}=3)$ and for $43 \mathrm{LxW}$ simulations it was 6 , that is, an area of $2.70 \mathrm{~m}^{2}$, in the three stages. In the 63 simulations, in stages R4 and R6 it has a LxW ratio of 12, an area of $5.40 \mathrm{~m}^{2}$ and for the R5.5 stadium the optimum size obtained was $6.30 \mathrm{~m}^{2}$, $\mathrm{LxW}=14$ (Table 4). 
Table 4 - Combination of length and width ( $\mathrm{LxW})$ and optimal plot size $\left(\mathrm{m}^{2}\right)$ obtained by the Modified Maximum Curvature (MMC) and Maximum Distance (MD) methods for the Coefficient of Variation (CV) and Variance (V) for stages R4, R5.5 and R6

\begin{tabular}{|c|c|c|c|c|c|}
\hline \multirow{2}{*}{ Stages } & \multirow{2}{*}{ Simulation } & \multicolumn{2}{|c|}{ MMC } & \multicolumn{2}{|c|}{ MD } \\
\hline & & $\mathrm{CV}$ & $\mathrm{V}$ & $\mathrm{CV}$ & $\mathrm{V}$ \\
\hline \multirow{6}{*}{$\mathrm{R} 4$} & 63 & $\mathrm{CxL}=1$ & $\mathrm{CxL}=1$ & $\mathrm{CxL}=12$ & $\mathrm{CxL}=1$ \\
\hline & & $\left(0.45 \mathrm{~m}^{2}\right)$ & $\left(0.45 \mathrm{~m}^{2}\right)$ & $\left(5.40 \mathrm{~m}^{2}\right)$ & $\left(0.45 \mathrm{~m}^{2}\right)$ \\
\hline & 43 & $\mathrm{CxL}=1$ & $\mathrm{CxL}=1$ & $\mathrm{CxL}=6$ & $\mathrm{CxL}=1$ \\
\hline & & $\left(0.45 \mathrm{~m}^{2}\right)$ & $\left(0.45 m^{2}\right)$ & $\left(2.70 \mathrm{~m}^{2}\right)$ & $\left(0.45 \mathrm{~m}^{2}\right)$ \\
\hline & 23 & $\mathrm{CxL}=1$ & $\mathrm{CxL}=1$ & $\mathrm{CxL}=3$ & $\mathrm{CxL}=1$ \\
\hline & & $\left(0.45 \mathrm{~m}^{2}\right)$ & $\left(0.45 \mathrm{~m}^{2}\right)$ & $\left(1.35 \mathrm{~m}^{2}\right)$ & $\left(0.45 \mathrm{~m}^{2}\right)$ \\
\hline \multirow{6}{*}{ R5.5 } & 63 & $\mathrm{CxL}=1$ & $\mathrm{CxL}=1$ & $\mathrm{CxL}=14$ & $\mathrm{CxL}=1$ \\
\hline & & $\left(0.45 \mathrm{~m}^{2}\right)$ & $\left(0.45 \mathrm{~m}^{2}\right)$ & $\left(6.30 \mathrm{~m}^{2}\right)$ & $\left(0.45 \mathrm{~m}^{2}\right)$ \\
\hline & 43 & $\mathrm{CxL}=1$ & $\mathrm{CxL}=1$ & $\mathrm{CxL}=6$ & $\mathrm{CxL}=1$ \\
\hline & & $\left(0.45 \mathrm{~m}^{2}\right)$ & $\left(0.45 m^{2}\right)$ & $\left(2.70 \mathrm{~m}^{2}\right)$ & $\left(0.45 \mathrm{~m}^{2}\right)$ \\
\hline & 23 & $\mathrm{CxL}=1$ & $\mathrm{CxL}=1$ & $\mathrm{CxL}=3$ & $\mathrm{CxL}=1$ \\
\hline & & $\left(0.45 \mathrm{~m}^{2}\right)$ & $\left(0.45 \mathrm{~m}^{2}\right)$ & $\left(1.35 \mathrm{~m}^{2}\right)$ & $\left(0.45 \mathrm{~m}^{2}\right)$ \\
\hline \multirow{6}{*}{ R6 } & 63 & $\mathrm{CxL}=1$ & $\mathrm{CxL}=1$ & $\mathrm{CxL}=12$ & $\mathrm{CxL}=1$ \\
\hline & & $\left(0.45 \mathrm{~m}^{2}\right)$ & $\left(0.45 \mathrm{~m}^{2}\right)$ & $\left(5.40 \mathrm{~m}^{2}\right)$ & $\left(0.45 \mathrm{~m}^{2}\right)$ \\
\hline & 43 & $\mathrm{CxL}=1$ & $\mathrm{CxL}=1$ & $\mathrm{CxL}=6$ & $\mathrm{CxL}=1$ \\
\hline & & $\left(0.45 \mathrm{~m}^{2}\right)$ & $\left(0.45 m^{2}\right)$ & $\left(2.70 \mathrm{~m}^{2}\right)$ & $\left(0.45 \mathrm{~m}^{2}\right)$ \\
\hline & 23 & $\mathrm{CxL}=1$ & $\mathrm{CxL}=1$ & $\mathrm{CxL}=3$ & $\mathrm{CxL}=1$ \\
\hline & & $\left(0.45 \mathrm{~m}^{2}\right)$ & $\left(0.45 \mathrm{~m}^{2}\right)$ & $\left(1.35 \mathrm{~m}^{2}\right)$ & $\left(0.45 \mathrm{~m}^{2}\right)$ \\
\hline
\end{tabular}

In order to have a higher quality in the data obtained, it is necessary to adopt the largest plot size, since the adoption of smaller plots leads to an increase in the experimental error and, consequently, the experimental precision decreases (LÚCIO and SARI, 2017). Thus, the optimal plot size for reflectance studies in soybean is $6.30 \mathrm{~m}^{2}$, two lines of $7 \mathrm{~m}$, or it is also possible to recommend the adoption of an immediately higher $\mathrm{LxW}$, in this case, $\mathrm{LxW}$ $=16$ or $7.20 \mathrm{~m}^{2}$, with grouping of 4 lines of $4 \mathrm{~m}$.

This plot size is smaller than that adopted by Cerezini et al. (2016) in their study, when they adopted $8.0 \mathrm{~m} 2$ plots for the study of early soy nodulation, by Hungary et al. (2015) who adopted $10.0 \mathrm{~m}^{2}$ plots in the study of herbicide resistance in biological nitrogen fixation and soybean production and by Durão and Boller (2017) who adopted an area of $11.25 \mathrm{~m}^{2}$ in the study of spray nozzles in rust control Asian soybean.

However, higher than estimated by Michels el al. (2016), who developed the study to analyze the effect of different numbers of fungicide application on soybean, using $5.4 \mathrm{~m}^{2}$ plots and by Rockenbach et al. (2016), who estimated the duration of the phenological phases of soybeans and adopted plots of $6.75 \mathrm{~m}^{2}$ in area. 


\section{Conclusions}

It was concluded that in studies that use reflectance measures in soybeans, it is recommended to use plots of $7.20 \mathrm{~m}^{2}$, with grouping of 4 lines of $4 \mathrm{~m}$.

\section{Acknowledgements}

We would like to thank reviewers and editors for their comments and suggestions.

MICHELS, R. N., CANTERI, M. G., AGUIAR E SILVA, M. A., BERTOZZI, J., DAL BOSCO, T. C. Estimação do tamanho ótimo de parcelas para experimento com radiômetro em soja. Rev. Bras. Biom. Lavras, v.39, n.2, p.362-371, 2021.

- RESUMO: A falta ou o erro do planejamento experimental em estudos agrícolas de campo pode resultar em retrabalho, ocasionando, o desperdício de recursos financeiros. A determinação do tamanho ótimo de parcela experimental para realização dos tratamentos pode minimizar estes problemas. $O$ objetivo deste trabalho foi estimar o tamanho ótimo de parcelas para medida de refletância em soja, sem tratamento, utilizando o método de curvatura máxima modificada e o método de máxima distância. Foram realizadas leituras de refletância na cultura da soja com auxílio do equipamento GreenSeeker ${ }^{\circledR}$, em unidades experimentais básicas de 0,45 $\mathrm{m}^{2}$, numa área de 7 linhas e 8 metros de comprimento. Os dados foram coletados em três estádios fenológicos da soja (R4, R5.5 e R6), obtendo-se 63 simulações de área experimental em cada estádio. Com base nos resultados, recomenda-se o uso de parcelas de 7,20 $\mathrm{m}^{2}$, com agrupamento de 4 linhas de $4 \mathrm{~m}$ de comprimento.

- PALAVRAS CHAVE: Curvatura máxima modificada; Máxima distância; NDVI.

\section{References}

BENEDUZZI, H. M.; SOUZA, E. G.; BAZZI, C. L.; SCHENATTO, K. Temporal variability in active reflectance sensor-measured NDVI in soybean and wheat crops. Engenharia Agrícola, v.37, n.4, p.771-781, 2017.

CARNEIRO, F. M.; FURLANI, C. E. A.; ZERBATO, C.; MENEZES, P. C.; GÍRIO, L. A. $\mathrm{S}$. Correlations among vegetation índices and peanut traits during different crop development stages. Engenharia Agrícola, v.39, p.33-40, 2019.

CEREZINI, P.; KUWANO, B. H.; SANTOS, M. B.; TERASSI, F.; HUNGRIA, M.; NOGUEIRA, M. A. Strategies to promote early nodulation in soybean under drought. Field Crops Research, v.196, p.160-167, 2016.

COELHO, A. P.; FARIA, R. T.; BARBOSA, A. M. S.; DALRI, A. B.; ROSALIN, D. L. Agronomic performance of white oats cultivated under fertigation with treated sewage effluent and definition of critical limits of Normalized Difference Vegetation Index. Bragantia, v.78, n. 4. p. 553-563, 2019.

DURÃO, C. F.; BOLLER, W. Spray nozzles performance in fungicides applications for Asian Soybean Rust control. Engenharia Agrícola, v.37, n.4, p.709-716, 2017.

HUNGRIA, M.; NAKATANI, R. A. S.; SEI, F. B.; CHUEIRE, L. M. O.; ARIAS, C. A. Impact of the ahas transgene for herbicides resistance on biological nitrogen fixation and yield of soybean. Transgenic Research, v.24, n.1, p. 155-165, 2015. 
KAPP JUNIOR, C.; GUIMARÃES, A. M.; CAIRES, E. F. Use of active canopy sensors to discriminate wheat response to nitrogen fertilization under no-tillage. Engenharia Agrícola, v.36, v.5, p.886-894, 2016.

LESSMAN, K. J.; ATKINS, R. E. Optimum plot size and relative efficiency of lattice designs for grain sorghum yield tests. Crop Science, v.3, p. 477-482, 1963.

LORENTZ, L. H.; ERICHSEN, R.; LUCIO, A. D. Proposta de método para estimação de tamanho de parcela para culturas agrícolas. Revista Ceres, v.59, n. 6, 2012.

LÚCIO, A. D.; SARI B. G. Planning and implementing experiments and analyzing experimental data in vegetable crops: problems and solutions. Horticultura Brasileira, v.35, n. 3, p.316-327, 2017.

MEIER, V. D.; LESSMAN, K. J. Estimation of optimum field plot shape and size for testing yield in Crambe abyssinica Hochst. Crop Science, v.11, p.648-650, 1971.

MICHELS, R. N. CANTERI, M. G.; FONSECA, I. C. B.; AGUIAR e SILVA, M. A.; FRANÇA, J. A. Estimation of optimal size of plots for experiments with radiometer in beans. African Journal of Biotechnology, v.14, p. 2361-2366, 2015.

MICHELS, R. N.; BONAFÉ, E. G.; FIGUEIREDO, L.; SUZUKI, R. M.; TONIN, L. D.; MONTANHER, P. F.; MARTINS, A. F.; VISENTAINER, J. V.; CANTERI, M. G.; AGUIAR e SILVA, M. A. Effects of different numbers of fungicide application on the proximate composition of soybean. Journal of the Brazilian Chemical Society, v.27, n. 10, p. 1727-1735, 2016.

PARANAÍBA, P. F.; MORAIS, A. R.; FERREIRA, D. F. Tamanho ótimo de parcelas experimentais: Comparação de métodos em experimento de trigo e mandioca. Revista Brasileira de Biometria, v.27, p. 71-81, 2009.

ROCKENBACH, A. P; CARON, B. O.; SOUZA, V. Q.; ELLI, E. F.; OLIVEIRA, D. M.; MONTEIRO, G. C. Estimated length of soybean phenological stage. Semina: Ciências Agrárias, v.37, n.4, p.1871-1882, 2016.

SANTOS, G. O.; ROSALEN, D. L.; FARIA, R. T. de. Use of active optical sensor in the characteristic's analysis of the fertigated brachiaria with treated sewage. Engenharia Agrícola, v.37, n.6, p.1213-1221, 2017.

SCHWERTNER, D.; LÚCIO, A. D.; CARGNELUTTI FILHO, A. Size of uniformity trials for estimating the optimum plot size for vegetables. Horticultura Brasileira, v.33, n.3, p.388-393, 2015.

STOCKER, V, SOUZA, E. G., JOHANN, J. A., BENEDUZZI, H., SILVA, F. O. Effect of height, tilt and twist angles of an active reflectance sensor on NDVI measurements. Engenharia Agrícola, v.39, p.96-108, 2019.

Received on 22.05.2020

Approved after revised on 16.11.2020 